\title{
Do Corporate Environmental Sustainability Practices Influence Firm Value? The Role of Independent Directors: Evidence from Saudi Arabia
}

\author{
Mohammed Abdullah Ammer ${ }^{1, *}$, Meqbel Mishary Aliedan ${ }^{2}$ and Mansour Abdullah Alyahya ${ }^{2}$ (D) \\ 1 Department of Finance, School of Business, King Faisal University, Al-Ahsa 31982, Saudi Arabia \\ 2 Department of Business Administration, School of Business, King Faisal University, \\ Al-Ahsa 31982, Saudi Arabia; maliedan@kfu.edu.sa (M.M.A.); malyahya@kfu.edu.sa (M.A.A.) \\ * Correspondence: mammer@kfu.edu.sa
}

Received: 8 October 2020; Accepted: 17 November 2020; Published: 23 November 2020

check for updates

\begin{abstract}
Environmental sustainability has become a significant approach for firms to enhance their competitive advantage and reputation. This study examines the association between environmental sustainability disclosures and firm value, in addition to the moderating impact of independent board directors on this association. Using data from Saudi listed firms, we find that reporting environmental sustainability practices has a positive and significant impact on firm value, suggesting that enhanced responsibility and transparency in addition to improved stakeholder trust are important in promoting firm value. We also find that the influence of the reported environmental sustainability practices on firm value is strongly and positively moderated by the presence of independent directors on firms' boards, signifying that stakeholders relate environmental reporting by firms to more independent directors providing better accountability to environmental practices. The implications of this study will be of great importance for policymakers, firm management, academia, and investors in considering the adoption and importance of firms' environmental practices.
\end{abstract}

Keywords: firm value; environmental sustainability; corporate governance; board independence; Saudi Arabia

\section{Introduction}

Global concerns about sustainable development and environmental issues have recently increased [1,2]. The Sustainable Stock Exchange (SSE) Initiative of the United Nations (UN) [3] indicates that by 2030, large firms are likely to disclose their influence from social and environmental practices. Environmental practices such as decreasing emissions and consuming resources are firm activities that affect firm stakeholders [4]. Thus, internal and external stakeholders are displaying a growing awareness of the environmental practices of firms due to the influence of the pollution being produced [5]. Recently, investors have employed environmental sustainability reporting as one of their mechanisms for investment decision-making [6,7]. Alsayegh et al. [8] indicated that firms have started to recognize the importance of properly considering sustainability approaches to achieve their future plans. To this end, firm value maximization can be related to a firm's reaction to its operating environment, which will motivate firms to go beyond limited and short-term financial concentrations.

Firms that actively consider the sustainability of environmental, social, and corporate governance (ESG) gain the advantages of greater value for both their community and their business [9]. Increasing environmental sustainability is associated with higher financial performance, as environmental sustainability disclosures will boost the legitimacy of firms [10]. Furthermore, previous evidence has revealed that green innovation may enhance the performance, competitive advantage, and product differentiation of firms [11,12]. Li et al. [13] argued that firms with improved environmental 
sustainability disclosures are more often targeted by investors and will have better relationships with their stakeholders. Therefore, the first objective of our study is to address the financial benefits for firms who engage in environmental sustainability reporting.

As a crucial element of success for firms, corporate governance has been related to better trust among investors and higher sustainability performance [14]. The board composition attributes are important to involve a firm in more sustainable practices [15]. This is because a board of directors is the key mechanism for corporate governance. The board is accountable for protecting the interests of firm stakeholders by guiding firm operations [16]. Among the board members, independent directors play a vital role in board effectiveness. Furthermore, corporate social responsibility (CSR) is better considered by independent directors [17]. Jizi [18] proposes that the existence of more independent members on the board will improve the legitimacy of CSR disclosure.

Therefore, to enhance value maximization and engage diverse stakeholders, boards will be more motivated to direct some of the firm resources towards investing and reporting on sustainable development $[19,20]$. Nevertheless, the association between the presence of independent board members and environmental sustainability is yet to be fully explored. Consequently, the second objective of this study is to investigate whether independent directors have a moderating impact on the relationship between environmental sustainability reporting and the value of their firm.

The financial market of Saudi Arabia is analytically interesting for several reasons. First, the literature concerning the association between environmental sustainability and the value of a firm is generally limited in developing markets. Thus, studying this issue in Saudi Arabia is still an emerging field. Second, Saudi Arabia is a petroleum-based country with a need for greater environmental sustainability. Saudi Arabia is an essential supplier of oil and gas to the world. Furthermore, achieving environmental sustainability is one of the main focuses of Saudi Vision 2030. This vision indicates that maintaining environmental sustainability is necessary for future generations and for the quality of people's daily lives. The Saudi government is currently working towards a significant decrease in $\mathrm{CO}_{2}$ emissions by 2030. Hence, environmental sustainability in Saudi Arabia has considerable implications for community welfare and business policy. Finally, in 2018, the Saudi Stock Exchange joined the SSE Initiative of the UN, through which corporations are directed to enhance their incorporation of sustainability in the Saudi capital market. Based on this partnership, the Saudi market will work to achieve social and environmental goals, including accountable production and consumption, as well as actions regarding the climate.

The latest Saudi code on corporate governance was published by the Capital Market Authority in 2019. According to this code, at least one third of board members should be non-executives, as per best practice. The code also stipulates that the majority of the board members should be non-executive directors, that board members should be appointed to their positions by a general assembly, and that such appointments should not last more than three years. Further, the code indicates that firms must establish a clear policy on social responsibility and contributions. The code mentions that the board of directors should launch programs and tools for achieving the firm policies and initiatives related to social responsibility.

Using a sample of 34 firms listed on the Saudi stock market for 2015-2019, we find positive, strong evidence of the relationship between environmental sustainability disclosures and firm value. The results indicate that the best practices for environmental sustainability by Saudi firms enhance the trust of stakeholders and increase firm value. This result is in line with stakeholder theory and legitimacy theory and provides strong evidence for encouraging environmental sustainability transparency. Additionally, consistent with agency theory, we find that independent directors moderate the association between environmental sustainability disclosures and firm value. The robustness of this result is examined in this paper using different techniques. First, we examine the impact of the aggregated score index of ESG on firm value. We find that ESG leads to higher firm value. Second, to confirm that our results are not dominated by one particular element of the environmental, social, and governance scores, we separately investigate the influence of social and governance disclosures on 
the value of a firm. We find a significant and positive influence of governance disclosure on the value of a firm. However, a positive but insignificant relationship is reported for social disclosure and the value of a firm.

Third, we substitute the measure of firm value (Tobin's $Q$ ) with accounting-based indicators (return on assets and return on equity) and market-based indicators (price-to-book value ratio). Again, environmental sustainability disclosures have a positive and strong association with the value of the firm. Finally, we implement the dynamic generalized method of moment (GMM) approach to check if our results have an endogeneity problem, again finding a strong positive association between environmental sustainability reporting and firm value; this association is significantly moderated by the presence of independent directors on boards.

This study makes some contributions to the current literature. First, this study adds to the limited previous evidence on the impact of firms' environmental sustainability practices on firm value. Further, the findings of a number of previous studies (e.g., [21,22]) are equivocal and inconclusive. Thus, to fill these gaps, more studies are required to simplify the convergence in addressing the association between environmental sustainability reporting and firm value. Second, while there are many studies conducted in developed markets, studies from developing countries, such as Saudi Arabia, remain scarce. This paper provides the first comprehensive study that investigates the influence of reporting environmental sustainability practices on firm value in the Saudi market. Third, Li et al. [13] call for examining the moderating factors of the association between ESG and firm value. Therefore, we extend the contributions of our study by investigating the moderating impact of independent directors on the association between disclosing environmental sustainability practices and the value of a firm. Finally, the results of this study will greatly help policy makers formulate environmental policies concerning the reduction of firms' operational effects on the environment. Furthermore, based on the results of our study, policy makers and firm management can increase their environmental practices by boosting the tools of corporate governance. Robust corporate governance is a vital mechanism to alleviate agency problems and help managers work effectively to ensure that stakeholders' interests are respected. Moreover, when firms incorporate sustainability practices in their strategies and reports, those firms will achieve superior sustainability and continuing value creation. Finally, the results illustrate that great transparency concerning environmental information may increase financial performance. Consequently, it will be worthwhile for investors to consider the significance of environmental disclosure.

The rest of this study is organized as follows. In Sections 2 and 3, we present the literature review and develop the hypotheses, respectively. Then, in Section 4, the samples and measurements of the variables are described. In Section 5, we provide the research models. Section 6 presents the main empirical results, as well as the additional and robustness analyses. Finally, in Section 7, we provide our conclusions.

\section{Literature Review}

\subsection{Corporate Environmental Sustainability Practices and Firm Value}

Environmental sustainability refers to the practices, activities, and efforts of firms to have a positive influence on the environment by decreasing environmental emissions in the processes of production and operations, in line with prevailing laws and a recognition of future effects [23]. The reporting of environmental sustainability practices is a vital mechanism for enhancing the transparency of firms and providing different stakeholders with the firm's strategies and rules concerning the natural environment $[24,25]$. The value of a firm is an indicator that compares book value and market value. Further, it represents the economic measurements that represent the market value of the entire business and reflect the total claims of the stockholders and debt holders [26].

Firm managers employ environmental policies to maintain a healthy environment and alleviate environmental damage [27]. Klassen and McLaughlin [28] claim that firms can enhance their financial 
performance by following the regulations related to decreasing their harmful to the environment emissions. Further, recognizing the environmental aspects of products will lead to increasing revenue [29]. When a firm allocates resources for environmental and green practices, their financial performance and competitive advantage will be enhanced and maintained [30].

The reactions of investors to industrial disasters will also be less negative for firms that disclose more environmental information, compared to other firms with less disclosed information [31]. Melnyk et al. [32] thus argue that the value of firms can be increased and that new investors can be attracted by improving firms' environmental performance. In effect, strong environmental activities help firms avoid any business influences as a result of pollution problems, which will result in saving costs [33].

On the empirical front, the financial performance of firms is affected by a decrease in emissions of $\mathrm{CO}_{2}$ and contamination, as this decrease will help effectively utilize resources and decrease waste [34]. Furthermore, it was reported that the financial performance of Chinese manufacturing firms is positively impacted by cleaner production [35]. Similarly, pulp and paper firms in the U.S. [36] and the tourism and hotel industries in diverse economic regions [37] are also strongly and positively influenced by the environmental performance. Firms' promises related to environmental activities further support financial performance [38]. Crifo and Forget [39] noted that when firms pay no attention to ESG concerns, those firms face great costs of capital and restricted access to private equity. It is thus argued that environmental policies will enhance innovations among firms, thereby decreasing the costs of compliance and promoting the competitiveness of firms [40].

As environmental sustainability disclosure is a part of ESG disclosure, past empirical studies on aggregated ESG disclosure can be highlighted. Li et al. [13] and Peiris and Evans [41] indicated that firms with greater value have greater ESG disclosures. Furthermore, Weber [42] reported that ESG reporting has a positive influence on firm value. It is proposed that enhanced firm value is a result of better transparency and responsibility among firms, as well as the confidence of stakeholders. In a meta-analysis of 251 studies, the authors in [43] determined that the general influence of a CSR on firm performance is positive.

\subsection{Moderating Role of Independent Directors}

In line with the development of environmental protection, it is the responsibility of the board of directors to make the decisions concerning environmental strategies [44] and monitor the environmental activities of the firm and its management $[45,46]$.

To perform its responsibilities, the board employs a mixture of both executive (inside) and non-executive (outside) directors. However, the use of non-executive directors by firms is aimed at monitoring the performance of executive directors to curtail opportunistic behavior $[47,48]$. The inside directors may act in their own interests to increase their personal wealth, as their goals may differ from those of shareholders. This will lead to agency problems. Jensen and Meckling [47] indicated that the role of independent directors is to reduce agency costs since such directors have the ability to control the opportunistic behavior of the inside directors. Further, Wang and Dewhirst [49] pointed out that independent directors have a better understanding of diverse stakeholders compared to executive directors.

McKendall et al. [45] claimed that independent directors can recognize the prospective long-term investments in issues related to the environment. Their concerns about social responsibility are strong [46], and they are expected to provide incentives to the executives of the firm to ensure good environmental performance [50].

In effect, independent directors support the disclosure of environmental plans to decrease agency costs and maintain their own reputations and recognition in society [51,52]. Accordingly, the presence of more independent directors will motivate the firms to maximize firm value based on long-term and greater transparency [53]. 
Empirically, a positive and strong relationship between independent directors and environmental practices has been reported $[10,54,55]$. Firms are expected to increase their sustainability reporting quality when their boards include more independent directors [56]. This requires that independent directors have a positive impact on the firm in disclosing high quality information and greater transparency to stakeholders [15]. Further, board independence is found to be positively associated with environmental sustainability reporting [57] and ESG disclosure [58]. Ibrahim and Angelidis [59] indicated that the social awareness among boards of directors is higher in firms that include a greater proportion of independent directors. It was also proposed in [44] that independent directors concentrate more on the compliance of the firm's management with regulations related to the environment. Haniffa and Cooke [60] indicated that independent directors pay more attention to the interests of firm stakeholders. Finally, the association between independent directors and CSR was found to be positive [61].

\section{Hypothesis Development}

\subsection{The Relationship between Corporate Environmental Sustainability Disclosure and Firm Value}

The theoretical argument for this study is that investments in developing environmental activities are paid off as decreased costs and improved profits [62]. Further, environmental products lead to reducing pollution costs under environmental rules. The incorporation of environmental elements into a firm's strategy will lead to developing environmental skills and possibly allow the firm to gain extra advantages in the market, compared to firms that do not consider environmental initiatives [27]. These environmental activities could support the images and reputations of firms [63] and produce an environmental brand [64] that will contribute to the overall value of the firms.

Stakeholder theory describes the relationship between reporting environmental sustainability practices and firm value. Disclosures of firm sustainability and responsibility are required by stakeholders to understand the functions of firm activities [65]. In line with stakeholder theory, the financial performance of firms is enhanced when the environmental or social requirements of stakeholders are achieved. Alsayegh et al. [8] argued that the competitive advantage for improving firm sustainability practices can be gained by disclosing ESG information to stakeholders. Thus, when competing in the market, stakeholders assume that a firm with better ESG performance has the ability to perform well [66]. Thus, these firms will be rewarded by stakeholders through greater investments by investors, more consumption by consumers, and greater productivity by employees [13], all resulting in higher firm value.

Legitimacy theory provides an additional incentive for environmental disclosure. This theory states that firms are able to exist and grow when they have community acceptance [67]. That is, disclosing environmental information is important to assure the community that the firm's operations are allowable and add to the norms, values, and expectations of the community [8]. Thus, firms will have superior opportunities in the market if they have the confidence and support of society. These opportunities can increase the ability for a firm to produce value [33]. In addition, for a firm to acquire legitimacy in its operations and decrease the risks that it might face, the firm needs to reveal information with enhanced quality [68].

Firms with environmentally distinguished products can enter markets that are characterized by growing environmental consciousness and enhance the market value of their green products [40]. Consumers with environmental awareness are expected to pay the increased prices of green products as a contribution to environmental development [69].

Thus, in line with stakeholder theory and legitimacy theory, firms are encouraged to disclose their environmental sustainability practices. The ways in which stakeholders recognize firm-disclosed environmental information is vital for evaluating firms in the stock market. Based on the above discussion, this study hypothesizes the following: 
Hypothesis 1 (H1). Environmental sustainability disclosure positively enhances the value of a firm.

\subsection{The Moderating Role of Independent Directors on the Relationship between Corporate Environmental} Sustainability Disclosure and Firm Value

Board independence is deemed by agency theory to be the most effective monitoring and controlling firm mechanism [48]. Thus, agency theory affirms the notion that it is better to have a high percentage of independent directors on board [15]. Unlike the classic emphasis on financial performance, independent directors are expected to offer innovative perspectives pertaining to the environmental and social interests of stakeholders. Naciti [15] claims that independent directors might be essential for observing and controlling the issue of sustainable development.

Independent directors have the ability to support the firm's management through operative ideas and guidance concerning environmental practices [24,25]. Masud et al. [57] argued that for independent directors to resolve agency conflicts, they provide a moderating role between the firm management and stakeholders. The presence of independent directors on a firm's board could provide wider stakeholder orientation, as such directors are more socially conscious of the requirements of various stakeholders [70]. In the same vein, boards with more independent directors can decrease the legitimacy gap between the firm and the community [71].

Independent directors have greater awareness about the importance of the environmental innovations and practices of the firm towards stakeholders like the government, investors, and lenders. Such directors are also aware of their personal reputations, which requires protection to ensure sustained director appointments.

In Saudi Arabia, the regulation of corporate governance reveals that independent directors are an essential component of board structures and firm governance. Independent directors are able to bring various perceptions to board discussions, thereby allowing a wider reflection of firm influences. In line with the above discussion, we examine the following hypothesis:

Hypothesis 2 (H2). The existence of independent directors on the board positively moderates the association between environmental sustainability disclosure and the value of the firm.

\section{Data and Methodology}

\subsection{Sample}

The sample of our study includes the firms listed on the TASI index (Saudi Stock Exchange) over the 2015-2019 period. We employ two categories of data. The first category involves financial data. The second involves data on firms' environmental sustainability disclosures. Data concerning environmental disclosures, boards of directors, and financial data were collected from Bloomberg. We utilized the Bloomberg database to gather the data since this database offers the disclosure indexes of ESG for firms and is extensively utilized by scholars. Until the end of 2019, there were 199 financial and non-financial listed firms on the main market of the Saudi Stock Exchange. Based on standard practice $[4,27,72], 47$ financial and 28 real estate investment firms were deleted due to their specific disclosure requirements and accounting codes of practice. We further eliminated 90 firms with missing variable data from our study, especially those missing data on our key variable of environmental sustainability, which is currently one of the key issues in Saudi Arabia. Thus, our final sample consists of 34 firms (170 firm-year observations). Based on the nature of this study, the population size was small and not enough to allow random sampling. We consequently employed purposeful sampling, as we aimed at investigating firms that were listed on the Saudi Stock Exchange during 2015-2019. One key advantage of our data is that our sample period runs from 2015 until the last year of available data, 2019. These data thus represent the most current scores available to clearly capture several features of firms' ESG sustainability disclosures. 


\subsection{Measurement of Variables}

\subsubsection{Measuring Firm Value}

Firm value is the dependent variable in this study. Thus, this study purposes to empirically examine the influences of environmental sustainability disclosure on firm value. Here, the firm value is measured by Tobin's Q, which is considered a valid measurement of firm value [13,52]. Specifically, this measurement reveals past values and accounts for a firm's forthcoming improvement prospects [73]. Further, Tobin's Q is considered a market-based indicator that is able to reflect a firm's net worth from an investor's perspective. Tobin's $Q$ is computed by dividing the market value of a firm's assets by the book value of those assets [74]. Tobin's $Q$ is a classic valuation measurement and has been employed widely in the literature of corporate governance [74], economics, and finance [75]. Finally, previous studies $[44,76]$ have indicated that better market-based performance produces improved environmental results.

To further test the influence of environmental disclosure on firm value, in our additional analyses, we test the influence of the environmental sustainability disclosure score on the value of a firm using different measurements, such as return on assets (ROA) and return on equity (ROE) (accounting-based measures), as well as the price-to-book value ratio (PBV) (a market-based indicator).

\subsubsection{Measuring Environmental Sustainability Disclosure}

The Saudi corporate governance code, issued in November 2006, indicates that all listed Saudi firms must provide non-financial reports regarding their governance, environmental, and social practices. The key experimental variable of this study is the environmental sustainability disclosure score. This score represents the efficiency and commitment of a firm concerning the protection of the environment during operations using better and more innovative solutions. Further, focusing on the environmental disclosure score will solve the issue where governance elements motivate the effects of ESG [77].

Our independent variable (the environmental sustainability disclosure score) is measured using the Bloomberg environmental disclosure scores [8,58]. We directly use the score variable for environmental sustainability disclosure instead of a categorical or binary variable. The scoring scheme ranges between 0 and 100 percent-zero percent for firms with no disclosed environmental information and one hundred percent for firms that disclose all related environmental information, as gathered by the analysts of Bloomberg.

\subsubsection{Measuring Independent Directors (Moderator)}

Firms that have a greater percentage of independent directors on their boards are expected to feature increased contributions of extra environmental practices and reporting. We use the independent directors on the boards as a moderating variable of the association between environmental sustainability disclosure and the value of the firm. The independent director variable is calculated as the percentage of independent directors compared to the overall number of directors on the board [55,58,78].

\subsubsection{Measuring Control Variables}

Following previous studies [79-81], some firm characteristics are employed as control variables that are suggested to affect firm value. Particularly, firm size (calculated as the logarithm of the firm's total assets) [10,50,55], firm market capitalization (computed as the total riyal market value of a firm's outstanding shares) [82], firm debt (the total debt to total assets ratio) [10,50,55], and firm risk (beta, calculated as the volatility of the stock price compared to the market index volatility) [10]. All data related to the control variables were collected from the Bloomberg database. 


\section{Research Model}

In this study, we test the associations between the environmental sustainability disclosure score (ENV) and firm value in addition to testing the moderating effect of independent directors on this association for Saudi Stock Exchange firms belonging to the TASI index.

To examine the first hypothesis of this study, we suggest that ENV disclosure will positively enhance the value of Saudi listed firms. Thus, the following regression model can be identified:

$$
\begin{gathered}
\text { TOBIN }_{i, t}=\beta_{0}+\beta_{1} \mathrm{ENV}_{i, t}+\beta_{2} \text { SIZE }_{i, t}+\beta_{3} \text { MARKETCAP }_{i, t}+\beta_{4} \text { DEBT }_{i, t}+\beta_{5} \text { BETA }_{i, t}+ \\
\text { Industry dummies }+ \text { Year dummies }+\varepsilon_{i, t}
\end{gathered}
$$

We then examine the second hypothesis that independent directors (BIND) positively moderate the association between the environmental disclosure scores and value of a firm. Accordingly, we employ the following regression model:

$$
\begin{aligned}
\text { TOBIN }_{i, t}= & \beta_{0}+\beta_{1} \text { BIND }_{i, t}+\beta_{2} \mathrm{ENV}_{\mathrm{i}, \mathrm{t}} \times \text { BIND }_{\mathrm{i}, \mathrm{t}}+\beta_{3} \mathrm{ENV}_{\mathrm{i}, \mathrm{t}}+\beta_{4} \mathrm{SIZE}_{\mathrm{i}, \mathrm{t}}+\beta_{5} \mathrm{MARKETCAP}_{\mathrm{i}, \mathrm{t}} \\
& +\beta_{6} \mathrm{DEBT}_{\mathrm{i}, \mathrm{t}}+\beta_{7} \mathrm{BETA}_{\mathrm{i}, \mathrm{t}}+\text { Industry dummies }+ \text { Year dummies }+\varepsilon_{\mathrm{i}, \mathrm{t}}
\end{aligned}
$$

where TOBIN, Tobin's $Q$, is computed by dividing the market value of a firm's assets by the book value of those assets. ENV is the environmental sustainability disclosure score. BIND, board independence, is the proportion of independent directors to the whole number of directors on the board. ENV $\times$ BIND is the moderating variable of the association between environmental sustainability disclosure and the value of the firm. SIZE, firm size, is calculated as the natural logarithm of a firm's total assets. MARKETCAP, market capitalization, is the total market value in riyals for the outstanding shares of firms. DEBT, firm debt, is the proportion of total debt to total assets. BETA, firm risk, is the volatility of the stock price compared to the market index volatility. Finally, the expressions (industry dummies) and (year dummies) indicate the unobserved industry fixed effect and time-specific effects that are time-variant and common to all firms.

In this study, we employed three panel regression methods. To handle the issue of independent observations for each firm over time, the hypotheses were first estimated by employing pooled ordinary least squares (OLS) utilizing robust standard errors clustered by firm and adjusted for heteroskedasticity. Then, the Breusch and Pagan Lagrangian multiplier test was conducted to identify the most appropriate estimator between pooled OLS and random effects. The random effects estimator was found to be better. Finally, the Hausman test was utilized to choose a suitable and effective estimator between the random effects and the fixed effects. The Hausman test indicated that the fixed effects estimator is the most efficient. Thus, both hypotheses were also tested by employing random effects alongside fixed effects regressions while controlling for time-invariant firm-specific effects.

\section{Empirical Results and Discussions}

\subsection{Descriptive Statistics and Pearson's Correlation}

Table 1 documents the summary statistics for the ENV disclosure scores of 34 Saudi firms over our sample period. In Table 1, Panel A, the level of environmental disclosure is close among all industries, except for the technology sector, where firms have a significantly higher ENV disclosure score (40.49), followed by firms elsewhere. In Table 1, Panel B, the ENV disclosure is approximately similar for firms over the years. However, the environmental disclosure score shows a positive tendency and slight growth from one year to the next until 2019, which indicates that firms are conscious of environmental disclosure's importance. Our results show consistency in environmental disclosure across different Saudi firms. 
Table 1. Descriptive statistics for environmental sustainability disclosure (ENV).

\begin{tabular}{cccc}
\hline \multicolumn{4}{c}{ Panel A: Environmental Disclosure within Each Industry } \\
\hline Industry & $\begin{array}{c}\text { Number of } \\
\text { Observations }\end{array}$ & Number of Firms & Mean \\
\hline Communication Services & 15 & 3 & 20.79 \\
Utilities & 10 & 2 & 14.38 \\
Consumer Goods & 30 & 6 & 15.33 \\
Health Care & 5 & 1 & 14.59 \\
Consumer Services & 20 & 4 & 22.97 \\
Materials & 50 & 10 & 18.57 \\
Oil and Gas & 10 & 2 & 20.63 \\
Technology & 20 & 4 & 40.49 \\
Industrials & 10 & 2 & 14.24 \\
\hline & Panel B: Environmental Disclosure during Each Year & \\
\hline Year & Number of & Number of Firms & \\
& Observations & 34 & 14.79 \\
2015 & 34 & 34 & 15.33 \\
2016 & 34 & 34 & 15.40 \\
2017 & 34 & 34 & 19.51 \\
\hline 2019 & 34 & 34 &
\end{tabular}

Table 2 outlines the descriptive statistics of the variables employed in this study. The mean of the dependent variable, TOBIN, is around 0.08. The means of the additional measurements for the firm values of ROE, ROA, and PBV are 0.90, 0.04, and 2.74, respectively. This reveals that TOBIN is higher than ROA but lower than ROE and PBV, respectively, for the period of 2015-2019. Moreover, TOBIN also shows a higher standard deviation (0.25) compared to ROA and ROE (but lower than PBV). This means that TOBIN has the highest variance among ROA and ROE, which have a standard deviation of only 0.07 and 0.15 , respectively. Our results are comparable to previous evidence (e.g., [83]).

Table 2. Descriptive statistics.

\begin{tabular}{|c|c|c|c|c|c|c|c|c|}
\hline Variables & $\mathbf{N}$ & Mean & STD & $\begin{array}{c}5 \text { th } \\
\text { Percentile }\end{array}$ & $\begin{array}{c}\text { 25th } \\
\text { Percentile }\end{array}$ & Median & $\begin{array}{c}\text { 75th } \\
\text { Percentile }\end{array}$ & $\begin{array}{c}\text { 95th } \\
\text { Percentile }\end{array}$ \\
\hline Tobin & 170 & 0.08 & 0.25 & 0.00 & 0.00 & 0.00 & 0.02 & 0.51 \\
\hline ROA & 170 & 0.04 & 0.07 & -0.02 & 0.01 & 0.02 & 0.05 & 0.21 \\
\hline PBV & 170 & 2.74 & 4.37 & 0.32 & 1.14 & 1.64 & 3.06 & 7.76 \\
\hline ENV & 170 & 16.21 & 15.84 & 1.79 & 2.68 & 10.08 & 30.23 & 44.96 \\
\hline ESG & 170 & 17.08 & 11.97 & 1.76 & 10.33 & 14.91 & 19.45 & 42.98 \\
\hline SOC & 133 & 17.13 & 13.43 & 1.79 & 7.02 & 12.28 & 23.95 & 47.37 \\
\hline GOV & 144 & 40.36 & 13.39 & 6.67 & 39.29 & 44.64 & 44.64 & 55.26 \\
\hline SIZE & 170 & 0.44 & 1.66 & 0.09 & 0.09 & 0.09 & 0.10 & 1.68 \\
\hline MARKETCAP & 170 & 4.92 & 54.64 & 0.07 & 0.21 & 0.51 & 0.99 & 1.77 \\
\hline DEBT & 170 & 22.76 & 20.23 & 0.00 & 4.51 & 15.86 & 39.78 & 58.55 \\
\hline
\end{tabular}

NOTE: In this table, the descriptive statistics for the variables used in our study are illustrated. Our study sample includes 170 observations covering 34 unique Saudi firms for the period 2015-2019.

In terms of our explanatory variable, the mean of the ENV disclosure score is approximately 16.21. The reported result indicates that, on average, the 34 Saudi firms are not resourcefully assigning their environmental expenditures to operative environmental practices since the environmental disclosure score ranges from 0 to 100 . 
We include the descriptive statistics of comprehensive ESG scores, social score (SOC), and governance score (GOV) in Table 2 since we use these statistics in subsequent analyses. As revealed in Table 2, the mean for the comprehensive ESG scores of the Saudi firms in our sample is 17.08. Further, the mean of the SOC score is 17.13, and that of the GOV score is 40.36, for the period 2015-2019. These results indicate that both the ENV and SOC scores have almost the same significance when modelling the total ESG score. However, the GOV score appears to have greater significance for modelling ESG in Saudi Arabia. Moreover, ENV disclosure shows a greater standard deviation of 15.84 than SOC (13.43) and GOV (13.39) disclosures. This highlights that the environmental practices of the Saudi firms are more volatile. Finally, Table 2 shows that the mean of board independence among Saudi firms is about 60.27. This is aligned with the Saudi code of corporate governance stipulations that at least one third of the board members be non-executives.

Table 3 presents the Pearson's correlation coefficients among our main variables. The correlation coefficients between ENV and the proxies of firm value (TOBIN and ROA) are positive and significant. However, ENV is positively but insignificantly related to ROE and PBV. Table 3 indicates that the ENV score is greatly and positively associated with firm size. This significant correlation indicates that large firms are inclined to engage in good environmental practices. To address the multicollinearity issue, we computed the variance inflation factors (VIF) and found that the corresponding values are small and do not surpass the critical value of 10 , which is an acceptable level. Therefore, the assumption of multicollinearity is not violated

Table 3. Correlation coefficients between variables.

\begin{tabular}{|c|c|c|c|c|c|c|c|c|c|}
\hline Variables & $\begin{array}{l}\frac{1}{0} \\
: 0\end{array}$ & $\sum_{i=1}$ & $\begin{array}{l}\text { 띴 } \\
\text { I }\end{array}$ & $\underset{\cong}{\mathbb{O}}$ & 商 & $\begin{array}{l}\text { N } \\
\text { ज }\end{array}$ & 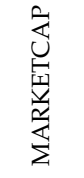 & 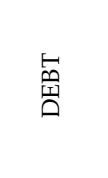 & $\overleftrightarrow{\mid 灬 ⿴ 囗 十 ~}$ \\
\hline Tobin & 1 & & & & & & & & \\
\hline ENV & $0.327^{* * *}$ & 1 & & & & & & & \\
\hline ROE & 0.050 & 0.129 & 1 & & & & & & \\
\hline ROA & 0.119 & $0.267^{* *}$ & $0.886^{* * *}$ & 1 & & & & & \\
\hline PBV & 0.148 & 0.618 & $0.319^{* * *}$ & $0.383^{* * *}$ & 1 & & & & \\
\hline SIZE & $0.442 * * *$ & $0.410^{* * *}$ & 0.009 & 0.168 * & $0.331^{* * *}$ & 1 & & & \\
\hline MARKETCAP & $0.182 *$ & 0.019 & -0.045 & 0.021 & -0.056 & $0.430^{* * *}$ & 1 & & \\
\hline DEBT & $0.266^{* *}$ & 0.084 & $-0.359^{* * *}$ & $-0.199 *$ & -0.047 & 0.155 & 0.113 & 1 & \\
\hline BETA & $-0.280^{* *}$ & $-0.495^{* * *}$ & 0.057 & -0.049 & $-0.353^{* * *}$ & $-0.339 * * *$ & 0.063 & -0.0681 & 1 \\
\hline
\end{tabular}

\subsection{Regression Results}

The regressions results are reported in this section using the three different estimators described for the research model. Table 4 outlines the outputs of regressing the firm value (TOBIN) on the environmental disclosure score (ENV). Table 4 also presents the moderating impact of independent directors on the environmental disclosure-firm value relationship. Here, we employ pooled OLS, as well as random effects and fixed effects regressions. As mentioned in Section 5, fixed effects regression is the most appropriate. Thus, our interpretations are based on the results of fixed effects regressions, although the results are similar among the three regressions. 
Table 4. The association between environmental sustainability disclosures and the value of Saudi listed firms, as well as the moderating impact of independent directors on this association.

\begin{tabular}{|c|c|c|c|}
\hline Variables & $\begin{array}{l}\text { Pooled OLS } \\
\text { (1) }\end{array}$ & $\begin{array}{c}\text { Random Effects } \\
\text { (2) }\end{array}$ & $\begin{array}{c}\text { Fixed Effects } \\
\text { (3) }\end{array}$ \\
\hline Intercept & $\begin{array}{l}14.215^{* * *} \\
(5.92)\end{array}$ & $\begin{array}{l}14.215^{* * *} \\
\quad(5.92)\end{array}$ & $\begin{array}{l}13.271^{* * *} \\
(7.67)\end{array}$ \\
\hline ENV & $\begin{array}{l}0.0034^{* * *} \\
(0.57)\end{array}$ & $\begin{array}{l}0.0066^{* * *} \\
(3.49)\end{array}$ & $\begin{array}{l}0.0088^{* * *} \\
\quad(4.71)\end{array}$ \\
\hline BIND & $\begin{array}{c}1.735^{* * *} \\
(13.34)\end{array}$ & $\begin{array}{c}1.341^{* * *} \\
(5.79)\end{array}$ & $\begin{array}{c}1.215^{* * *} \\
(7.62)\end{array}$ \\
\hline $\mathrm{ENV} \times \mathrm{BIND}$ & $\begin{array}{c}0.099 * * * \\
(99.66)\end{array}$ & $\begin{array}{c}0.098 * * * \\
(55.03)\end{array}$ & $\begin{array}{c}0.096^{* * *} \\
(54.02)\end{array}$ \\
\hline SIZE & $\begin{array}{l}0.208^{* * *} \\
(2.80)\end{array}$ & $\begin{array}{l}0.129 * \\
(1.84)\end{array}$ & $\begin{array}{l}0.126^{*} \\
(2.00)\end{array}$ \\
\hline MARKETCAP & $\begin{array}{c}0.764^{* *} \\
(2.06)\end{array}$ & $\begin{array}{l}-0.222 \\
(-0.75)\end{array}$ & $\begin{array}{l}-0.583 \\
(-1.29)\end{array}$ \\
\hline DEBT & $\begin{array}{c}-0.0228^{* * * *} \\
(-2.78)\end{array}$ & $\begin{array}{c}-0.0103 \\
(-0.76)\end{array}$ & $\begin{array}{l}-0.0054 \\
(-0.20)\end{array}$ \\
\hline BETA & $\begin{array}{l}-0.182 \\
(-1.63)\end{array}$ & $\begin{array}{l}0.065 \\
(1.12)\end{array}$ & $\begin{array}{l}0.093 \\
(1.65)\end{array}$ \\
\hline Year_FE & Yes & Yes & Yes \\
\hline Industry_FE & Yes & Yes & Yes \\
\hline Sample Size & 119 & 119 & 119 \\
\hline F-value & $1735.24^{* * *}$ & $594.55^{* * *}$ & $580.60^{* * * *}$ \\
\hline Adjusted $\mathrm{R}^{2}$ & 0.790 & 0.390 & 0.388 \\
\hline Breusch-Pagan LM test & & $73.88^{* * *}$ & \\
\hline Hausman Test & & $515.93^{* * *}$ & \\
\hline
\end{tabular}

NOTE: In this table, the findings from regressing ENV on Tobin, as well as BIND, on the association between ENV and Tobin are reported. Hypotheses are tested using pooled OLS, random effects, and fixed effects, respectively. The control variables are firm size (SIZE), market capitalization (MARKETCAP), firm debt (DEBT), and firm risk (BETA). ${ }^{* * *}, * *$, and $*$ illustrate the significance levels at $1 \%, 5 \%$, and $10 \%$, respectively.

In model (3) of Table 4, the result of the fixed effects regression provides support for hypothesis H1, indicating that the environmental disclosure scores positively enhance the value of the Saudi firms. Such a result suggests that a greater level of firm environmental disclosures leads to higher firm value. This result is proven by model (1) and (2) for pooled OLS and random effects, respectively. Indeed, ENV is still positively and significantly associated with TOBIN. This result lends strong support to stakeholder theory and legitimacy theory, demonstrating a positive ENV-value association, highlighting that the consciousness and demand among stakeholders for ENV is increasing and that stakeholders integrate ENV disclosures alongside other investment information. Therefore, sustaining the requirements of stakeholders could yield superior performance and value among firms.

Further, our results specify that the development of environmental sustainability activity reporting enables firms to gain the support of consumers and achieve a competitive advantage. Likewise, the improvement in environmental activities allow firms to build their intangible asset value [84]. An increase in environmental practices among firms leads investors to assume greater development in financial performance via income growth and improved efficiency. Consequently, investors will be more inclined to pay more for these firms' stocks, and the value of the firm will be increased [32]. Our result is in line with prior evidence [34-37].

Regarding the control variables, our results show a high value for large firms (SIZE). These results suggest that firm value is linked to the firm's characteristics, which is consistent with prior evidence in the literature (e.g., [8]). Alsayegh et al. [8] report that the capabilities of big firms to 
carry out their operations and efficiently design their procedures will result in improved corporate sustainability practices.

This study proposes to provide new knowledge by demonstrating that board independence has a moderating influence on the association between ENV and the value of a firm. Table 4 also presents the results of regressing the independent directors on board (BIND) based on the association between ENV and TOBIN using fixed effects regressions in addition to pooled OLS and random effects. Thus, to examine our hypothesis $\mathbf{H 2}$, the interaction term $(\mathrm{ENV} \times \mathrm{BIND})$ is used as the key variable. The interaction term highlights the difference in the influence of ENV on the value of Saudi firms when considering boards with high and low independent directors. In Table 4, the coefficient estimates of BIND in all models are positive and significant, demonstrating that boards with more independent directors increase firm value. Further, the results in model (3) for fixed effects provide support for the second hypothesis $\mathbf{H 2}$, indicating a positive effect of independent directors on the association between ENV and firm value. Our estimated coefficient of ENV $\times$ BIND is statistically positive and significant, demonstrating that the positive influence of environmental disclosures on the value of a firm is further enhanced by the existence of more independent directors on a firm's board.

Models (1) and (2) in Table 4, which employ pooled OLS and random effects, confirm the first result. The interaction term ENV $\times$ BIND is still statistically positive and significant. This result indicates that boards with more independent directors are motivated to enhance their firms' ENV plans. This result is in line with agency theory, as independent directors boost investments in ENV and provide greater transparency.

This result is in line with the authors in [85], who noted that independent directors have great awareness of environmental initiatives and activities. Further, this result supports the argument in [57] that independent directors perform a vital moderating role between the management of a firm and different stakeholders, which results in resolving agency conflicts.

These results offer strong evidence that the characteristics of board governance have an influence on environmental practices. A plausible explanation for this result is that board independence exists not only to adhere to the best practices of the Saudi code of corporate governance (which requires that one third of board members be independent) but also to provide strict overseeing of management activities. The average number of independent directors on boards in this study was 60.27 , as reported in Table 2. Thus, independent directors dominate the boards, which enables those boards to perform better in enhancing their firms' environmental practices. This result reveals that the composition of one third of independent directors, as stipulated by the Saudi code of corporate governance, is adequate.

To summarize, our results indicate that the value of Saudi firms increases with greater ENV disclosure. Furthermore, for the relationship with ENV disclosure, the firm value becomes stronger when the board includes more independent directors.

\subsection{Additional Analysis}

It is argued that investors provide diverse weights to the factors of ESG disclosure scores $[77,86]$. Thus, we conducted an additional analysis to examine how the comprehensive ESG score and its individual factors of SOC and GOV scores influence firm value in Saudi Arabia.

Table 5 documents the results of regressing firm value on ESG, SOC, and GOV disclosures using pooled OLS and fixed effects regressions. In models (1) and (2) in Table 5, the estimated coefficient of ESG is statistically significant and positive, showing that the value of firms will increase with a greater level of environmental, social, and governance disclosures. These results are similar to those in various studies (e.g., $[4,87,88])$. For the separate SOC score, the results in models $(4)$ and (5) are found to be positive but not statistically significant, indicating that there is no influence of social disclosures on firm value, which is consistent with the results in [89]. Finally, the coefficient associated with GOV in models (5) and (6) is statistically significant and positive, indicating that governance disclosures have a positive influence on firm value. 
Table 5. The influence of comprehensive environmental, social, and corporate governance (ESG) and social (SOC) and governance (GOV) disclosures on the value of Saudi listed firms.

\begin{tabular}{|c|c|c|c|c|c|c|}
\hline \multirow[b]{2}{*}{ Variables } & \multicolumn{2}{|c|}{ ESG } & \multicolumn{2}{|c|}{ SOC } & \multicolumn{2}{|c|}{ GOV } \\
\hline & $\begin{array}{l}\text { Pooled OLS } \\
\text { (1) }\end{array}$ & $\begin{array}{l}\text { Fixed Effects } \\
\text { (2) }\end{array}$ & $\begin{array}{l}\text { Pooled OLS } \\
\text { (3) }\end{array}$ & $\begin{array}{l}\text { Fixed Effects } \\
\text { (4) }\end{array}$ & $\begin{array}{l}\text { Pooled OLS } \\
\text { (5) }\end{array}$ & $\begin{array}{c}\text { Fixed Effects } \\
\text { (6) }\end{array}$ \\
\hline Intercept & $\begin{array}{c}17.122 * * * \\
(7.18)\end{array}$ & $\begin{array}{l}13.344 \\
(1.35)\end{array}$ & $\begin{array}{c}15.252 * * * \\
(5.10)\end{array}$ & $\begin{array}{l}19.699 \\
(1.18)\end{array}$ & $\begin{array}{c}42.524^{* * *} \\
(15.28)\end{array}$ & $\begin{array}{c}35.364 * \\
(2.02)\end{array}$ \\
\hline ESG & $\begin{array}{l}0.054 * \\
(2.42)\end{array}$ & $\begin{array}{l}0.052 * \\
(2.25)\end{array}$ & & & & \\
\hline SOC & & & $\begin{array}{l}0.010 \\
(0.32)\end{array}$ & $\begin{array}{l}0.011 \\
(0.34)\end{array}$ & & \\
\hline GOV & & & & & $\begin{array}{l}0.062 * \\
(-1.83)\end{array}$ & $\begin{array}{l}0.068^{*} \\
(-1.92)\end{array}$ \\
\hline SIZE & $\begin{array}{c}2.831 * * * \\
(-8.68)\end{array}$ & $\begin{array}{c}2.884^{* * *} \\
(-8.64)\end{array}$ & $\begin{array}{l}2.267^{* * *} \\
(-4.94)\end{array}$ & $\begin{array}{c}2.286^{* * *} \\
(-4.88)\end{array}$ & $\begin{array}{l}1.483 \text { ** } \\
(-2.84)\end{array}$ & $\begin{array}{l}1.703^{* *} \\
(-3.16)\end{array}$ \\
\hline MARKETCAP & $\begin{array}{l}0.037^{*} \\
(2.33)\end{array}$ & $\begin{array}{l}1.109 \\
(0.58)\end{array}$ & $\begin{array}{l}0.021 \\
(1.11)\end{array}$ & $\begin{array}{l}0.172 \\
(0.06)\end{array}$ & $\begin{array}{l}-0.009 \\
(-0.45)\end{array}$ & $\begin{array}{l}0.793 \\
(0.27)\end{array}$ \\
\hline DEBT & $\begin{array}{l}0.026 \\
(0.36)\end{array}$ & $\begin{array}{l}-0.035 \\
(-0.22)\end{array}$ & $\begin{array}{l}0.151 \\
(1.59)\end{array}$ & $\begin{array}{l}-0.114 \\
(-0.53)\end{array}$ & $\begin{array}{l}-0.067 \\
(-0.75)\end{array}$ & $\begin{array}{l}0.041 \\
(0.17)\end{array}$ \\
\hline BETA & $\begin{array}{l}-0.613 \\
(-1.30)\end{array}$ & $\begin{array}{l}-0.694 \\
(-1.40)\end{array}$ & $\begin{array}{l}-0.788 \\
(-1.25)\end{array}$ & $\begin{array}{l}-0.618 \\
(-0.94)\end{array}$ & $\begin{array}{l}1.443^{*} \\
(2.08)\end{array}$ & $\begin{array}{l}1.256 \\
(1.68)\end{array}$ \\
\hline Year_FE & Yes & Yes & Yes & Yes & Yes & Yes \\
\hline Industry_FE & Yes & Yes & Yes & Yes & Yes & Yes \\
\hline Sample Size & 170 & 170 & 129 & 129 & 140 & 140 \\
\hline F-value & $90.41^{* * *}$ & $17.44^{* * *}$ & $23.39 * * *$ & $4.76^{* * *}$ & $27.78^{* * *}$ & $5.49^{* * *}$ \\
\hline Adjusted $R^{2}$ & 0.405 & 0.407 & 0.211 & 0.224 & 0.185 & 0.188 \\
\hline
\end{tabular}

NOTE: In this table, the results from regressing Tobin on ESG, SOC, and GOV disclosures are reported using pooled OLS and fixed effects, respectively. The control variables are firm size (SIZE), market capitalization (MARKETCAP), firm debt (DEBT), and firm risk (BETA). ${ }^{* * *}, * *$, and * illustrate the significance levels at $1 \%, 5 \%$, and $10 \%$, respectively.

\subsection{Robustness Checks}

To check the robustness of the key result, that ENV disclosure positively enhances the value of Saudi firms and that this enhancement is moderated by independent directors, some robustness regressions are conducted in the following section.

\subsubsection{Alternative Measures of Firm Value}

Alshehhi et al. [90] indicated that additional studies are required to outline and classify appropriate corporate financial measures and show how these measures are associated with sustainability practices. Therefore, to further assess our findings, we next retest our main models by employing alternative and well-accepted measurements of firm value. Table 6 reports the regression results from running the same two regression models in Table 4 but while employing accounting-based indicators (return on equity and return on assets) and a market-based indicator (price-to-book value ratio) as dependent variables instead of TOBIN. Similar to our main results reported in Table 4, the estimated coefficient of ENV still positively and significantly related with the other firm value measures (ROE, ROA, and PBV). That is, a higher ROE, ROA, and PBV indicate a higher firm value. 
Table 6. Robustness regression with return on equity (ROE), return on assets (ROA), and price-to-book value ratio (PBV) as dependent variables.

\begin{tabular}{|c|c|c|c|c|c|c|}
\hline \multirow{2}{*}{ Variables } & \multicolumn{2}{|c|}{ ROE } & \multicolumn{2}{|c|}{ ROA } & \multicolumn{2}{|c|}{ PBV } \\
\hline & $\begin{array}{l}\text { Pooled OLS } \\
\text { (1) }\end{array}$ & $\begin{array}{l}\text { Fixed Effects } \\
\text { (2) }\end{array}$ & $\begin{array}{l}\text { Pooled OLS } \\
\text { (3) }\end{array}$ & $\begin{array}{l}\text { Fixed Effects } \\
\text { (4) }\end{array}$ & $\begin{array}{l}\text { Pooled OLS } \\
\text { (5) }\end{array}$ & $\begin{array}{l}\text { Fixed Effects } \\
\text { (6) }\end{array}$ \\
\hline Intercept & $\begin{array}{c}13.430 * * * \\
(4.01)\end{array}$ & $\begin{array}{l}2.230 \\
(0.29)\end{array}$ & $\begin{array}{c}9.675 * * \\
(2.09)\end{array}$ & $\begin{array}{l}-10.562 \\
(-1.45)\end{array}$ & $\begin{array}{c}12.183 * * \\
(3.34)\end{array}$ & $\begin{array}{l}3.786 \\
(0.58)\end{array}$ \\
\hline ENV & $\begin{array}{l}0.096^{* *} \\
(2.12)\end{array}$ & $\begin{array}{l}0.110^{* *} \\
(2.34)\end{array}$ & $\begin{array}{l}0.435^{* *} \\
(3.26)\end{array}$ & $\begin{array}{c}0.590 * * * \\
(3.87)\end{array}$ & $\begin{array}{l}0.088^{*} \\
(-1.88)\end{array}$ & $\begin{array}{l}0.096^{* *} \\
(-2.12)\end{array}$ \\
\hline SIZE & $\begin{array}{l}0.707^{* *} \\
(3.05)\end{array}$ & $\begin{array}{l}0.642^{* *} \\
(2.76)\end{array}$ & $\begin{array}{c}0.803^{* * *} \\
(3.66)\end{array}$ & $\begin{array}{l}0.749^{* *} \\
(3.49)\end{array}$ & $\begin{array}{l}0.739 * \\
(2.59)\end{array}$ & $\begin{array}{l}0.674^{*} \\
(2.35)\end{array}$ \\
\hline MARKETCAP & $\begin{array}{l}0.022 \\
(0.98) \\
\end{array}$ & $\begin{array}{l}1.942 \\
(1.44)\end{array}$ & $\begin{array}{l}0.008 \\
(0.38)\end{array}$ & $\begin{array}{l}3.743 * * \\
(2.93)\end{array}$ & $\begin{array}{c}0.020 * * * \\
(4.39)\end{array}$ & $\begin{array}{l}1.482 \\
(1.44)\end{array}$ \\
\hline DEBT & $\begin{array}{l}0.081 \\
(0.89) \\
\end{array}$ & $\begin{array}{l}0.117 \\
(0.92)\end{array}$ & $\begin{array}{l}0.069 \\
(0.82)\end{array}$ & $\begin{array}{l}0.058 \\
(0.53)\end{array}$ & $\begin{array}{l}0.062 \\
(0.70)\end{array}$ & $\begin{array}{l}0.083 \\
(0.73)\end{array}$ \\
\hline BETA & $\begin{array}{c}-1.247^{* * *} \\
(-3.77)\end{array}$ & $\begin{array}{c}-1.320 * * * \\
(-3.91)\end{array}$ & $\begin{array}{l}-0.119 \\
(-0.32)\end{array}$ & $\begin{array}{l}-0.142 \\
(-0.39)\end{array}$ & $\begin{array}{l}-0.318 \\
(-0.87)\end{array}$ & $\begin{array}{l}-0.306 \\
(-0.89)\end{array}$ \\
\hline Year_FE & Yes & Yes & Yes & Yes & Yes & Yes \\
\hline Industry_FE & Yes & Yes & Yes & Yes & Yes & Yes \\
\hline Sample Size & 170 & 170 & 170 & 170 & 170 & 170 \\
\hline F-value & $29.01 * * *$ & $5.68^{* * *}$ & $73.51^{* * *}$ & $9.13^{* * *}$ & $67.71^{* * *}$ & $3.39 * * *$ \\
\hline Adjusted $\mathrm{R}^{2}$ & 0.184 & 0.199 & 0.382 & 0.428 & 0.347 & 0.356 \\
\hline
\end{tabular}

\subsubsection{Endogeneity}

The main Equations (1) and (2) are estimated with pooled OLS, random effect, and fixed effect regressions, and all standard errors are modified for firm-level clustering. However, the relationship between environmental disclosures and firm value could involve a potential endogeneity problem. That is, omitted unobservable firm characteristics, both variable and fixed in time (e.g., culture and religion), could impact both environmental disclosure and firm value. In addition, Jo et al. [91] underlined the reasons to assume the presence of reverse causality. Accordingly, greener corporations may be more profitable, but it is also possible that firm performance will affect environmental disclosure. In this situation, under pooled OLS, random effects and fixed effects would not be appropriate. To alleviate this endogeneity concern, we implement a dynamic panel GMM estimator.

The results of the dynamic panel GMM approach are presented in Table 7. This model incorporates the dynamic relationship between ENV, the moderator effect of the board independent director, and TOBIN. We further support our first hypothesis by reporting the significantly positive coefficient for ENV, indicating that the positive association between environmental sustainability reporting and firm value holds true after controlling for endogeneity based on the dynamic GMM estimator. As seen in Table 7, the estimated coefficient for the lag of the dependent variable is significantly and positively related to firm value. This finding indicates that the association between ENV and firm value is robust against dynamic endogeneity. We found similar results for our second hypothesis. Thus, the positive effect of environmental disclosures on firm value is enhanced by the existence of independent directors on the board. 
Table 7. Addressing endogeneity: the GMM approach.

\begin{tabular}{|c|c|}
\hline Variables & GMM \\
\hline Intercept & $\begin{array}{c}1.014^{* * *} \\
(3.99)\end{array}$ \\
\hline ENV & $\begin{array}{c}0.044^{* *} \\
(2.84)\end{array}$ \\
\hline LAGTOBIN & $\begin{array}{c}0.283 \text { ** } \\
(2.07)\end{array}$ \\
\hline BIND & $\begin{array}{c}1.680 * * * \\
(3.96)\end{array}$ \\
\hline $\mathrm{ENV} \times \mathrm{BIND}$ & $\begin{array}{c}0.075^{* * *} \\
(5.00)\end{array}$ \\
\hline SIZE & $\begin{array}{c}2.244^{* *} \\
(2.16)\end{array}$ \\
\hline MARKETCAP & $\begin{array}{l}0.584 \\
(0.82)\end{array}$ \\
\hline DEBT & $\begin{array}{l}-0.009 \\
(-0.34)\end{array}$ \\
\hline BETA & $\begin{array}{l}-0.0100 \\
(-0.84)\end{array}$ \\
\hline Year_FE & Yes \\
\hline Industry_FE & Yes \\
\hline Sample Size & 95 \\
\hline F-value & $5647.29^{* * *}$ \\
\hline $\mathrm{AR}(1)$ test (p-value) & -2.12 \\
\hline $\operatorname{AR}(2)$ test (p-value) & 1.02 \\
\hline Hansen-J test of over-identification ( $p$-value) & 15.86 \\
\hline
\end{tabular}

NOTE: the findings from regressing ENV on Tobin, as well as BIND, on the association between ENV and Tobin and other control variables are reported in this Table using the GMM approach. The control variables are firm size (SIZE), market capitalization (MARKETCAP), firm debt (DEBT), and firm risk (BETA). ${ }^{* * *}, * *$, and * illustrate the significance levels at $1 \%, 5 \%$, and $10 \%$, respectively.

\section{Conclusions}

The main purpose of our study was to examine the influence of environmental sustainability disclosures on the value of Saudi listed firms and to examine the moderating impact of independent directors on this influence. The results of this study provide strong empirical evidence that environmental sustainability disclosures lead to greater firm value in the Saudi financial market. These results are consistent with stakeholder theory and legitimacy theory. Furthermore, consistent with agency theory, we provide robust evidence that including more independent directors on the boards of Saudi firms positively enhances the association between environmental sustainability disclosures and firm value. An additional analysis was performed using the aggregate ESG scores as our independent variable. The results indicate that ESG scores have a positive impact on firm value. Further, we conducted another analysis using the individual factors of the ESG scores. Specifically, we used social disclosure and governance disclosure as the independent variables. While the governance disclosure was found to have a strong impact on firm value, the social disclosure was positively but insignificantly related to firm value.

Robustness analyses of the main results were also conducted. We used different measurements for the firm value instead of Tobin's Q. We utilized accounting-based indicators (return on assets and return on equity) and market-based indicators (price-to-book value ratio). All results confirm that environmental sustainability reporting enhances Saudi firm value. Additionally, to overcome the endogeneity concerns, we implemented a dynamic panel GMM estimator. We found similar results 
indicating that there is a strong positive association between environmental disclosures and the value of Saudi firms.

Our study was stimulated by the scarcity of comprehensive research on the importance of environmental reporting in developing countries. Specifically, research that provides in-depth insight into environmental sustainability, corporate governance, and firm value in this context are rare. As such, this study minimizes this gap in the literature. In this way, we contribute to the literature by examining whether environmental sustainability disclosures influence firm value. Another contribution to the extant academic literature is our examination of the moderating influence of board-independent directors on the association between environmental sustainability disclosures and the value of a firm. This study's results are anticipated to support the academic community and other researchers. Further, we adopted a multi-theoretical method that comprises several theories, such as stakeholder theory, legitimacy theory, and agency theory. These are the main theories that underpin the hypothesis development of our study. This study contributes to both stakeholder theory and legitimacy theory by enhancing the understanding of environmental sustainability and its effects on the value of firms in Saudi Arabia. Further, this study adds to agency theory by highlighting the positive role of independent directors in moderating the relationship between environmental sustainability disclosures and firm value.

To improve environmental sustainability practices and disclosures, the practical implications of this study will be of interest to regulators, firm management, and investors. The disclosure levels of environmental and comprehensive ESG in Saudi firms presented in this study were lower than the levels documented in other countries. Thus, it is worthwhile for capital market authorities to encourage firms in Saudi Arabia to include ESG elements in their reporting. After COVID-19, many investors have started paying more attention to sustainable and low-carbon business. Thus, in line with international agreements and indices of the environment, society, and governance, the Saudi market authorities also need to launch their own index. Further, the market authorities should ensure that the directors on the board are more aware of the importance that environmental sustainability can provide for firms. For example, the directors could promote environmental sustainability awareness among firms by conducting seminars and training workshops. These are significant steps for increasing investments in firms and attracting more foreign investors into the country.

Further, the results illustrate that independent directors represent a good mechanism and undertake active positions in supporting environmental disclosures and firm value. Thus, for firms to report their initiatives related to environmental issues, it is recommended to guarantee the existence of independent directors on their boards. Additionally, as environmental disclosure has a significant role in investment decisions, our results suggest that Saudi firms should look for further techniques to attract and sustain investors via allocating resources to suitable environmental activities and initiatives. Investors might include environmental disclosure scores into their strategies and considerations, which will help such investors determine potential deviations in the future performance of firms. If shareholders are capable of obtaining reliable information with reference to the performance of the firm in environmental issues, the financial decisions of such shareholders will be more accurate and efficient.

As with any study, the present analysis is subject to some limitations that should be highlighted. These limitations present possibilities for, and encourage the development of, future studies. First, as this study excluded all financial and real estate firms due to their different regulations (along with firms with missing data, particularly data on environmental sustainability disclosures, the final sample was small). Therefore, future studies should use larger samples. Second, this study employed Saudi data. Thus, concern should be taken in generalizing these results to capital markets in other countries, which might have different attributes related to size, regulations, practices, and market valuation. Thus, it is worth extending this study in the future to further markets, particularly emerging markets and transition economies. Third, the present study includes independent directors only as an active corporate governance mechanism. Hence, future studies could employ different mechanisms to clarify 
the environmental sustainability disclosure-firm value relationship. For instance, it would be valuable to test the moderating influence of ownership structure on this relationship.

Author Contributions: M.M.A. designed the research. M.A.A. (Mohammed Abdullah Ammer) conducted the research and analyzed the data. M.A.A. (Mohammed Abdullah Ammer), M.M.A., and M.A.A. (Mansour Abdullah Alyahya). wrote the paper. All authors have read and agreed to the published version of the manuscript.

Funding: This research was funded by the Deputyship for Research and Innovation, Ministry of Education in Saudi Arabia.

Acknowledgments: The authors extend their appreciation to the Deputyship for Research and Innovation, Ministry of Education, in Saudi Arabia for funding this research work through the project number IFT20037.

Conflicts of Interest: The authors declare no conflict of interest.

\section{References}

1. Borghesi, S.; Cainelli, G.; Mazzanti, M. Linking emission trading to environmental innovation: Evidence from the Italian manufacturing industry. Res. Policy 2015, 44, 669-683. [CrossRef]

2. Guo, Y.; Wang, L.; Yang, Q. Do corporate environmental ethics influence firms' green practice? The mediating role of green innovation and the moderating role of personal ties. J. Clean. Prod. 2020, 266, 122054. [CrossRef]

3. Sustainable Stock Exchanges (SSE). Sustainable Stock Exchanges Initiative: Model Guidance on Reporting ESG Information to Investors. Available online: https://sseinitiative.org/wp-content/uploads/2015/09/SSEModel-Guidance-on-Reporting-ESG.pdf (accessed on 6 August 2020).

4. Yoon, B.; Lee, J.H.; Byun, R. Does ESG Performance Enhance Firm Value? Evidence from Korea. Sustainability 2018, 10, 3635. [CrossRef]

5. Jasch, C. Environmental management accounting (EMA) as the next step in the evolution of management accounting. J. Clean. Prod. 2006, 14, 1190-1193. [CrossRef]

6. Khan, M.; Serafeim, G.; Yoon, A. Corporate Sustainability: First Evidence on Materiality. Account. Rev. 2016, 91, 1697-1724. [CrossRef]

7. Kim, Y.; Park, M.S.; Wier, B. Is earnings quality associated with corporate social responsibility? Account. Rev. 2012, 87, 761-796. [CrossRef]

8. Alsayegh, M.F.; Rahman, R.A.; Homayoun, S. Corporate Economic, Environmental, and Social Sustainability Performance Transformation through ESG Disclosure. Sustainability 2020, 12, 3910. [CrossRef]

9. Taliento, M.; Favino, C.; Netti, A. Impact of Environmental, Social, and Governance Information on Economic Performance: Evidence of a Corporate 'Sustainability Advantage' from Europe. Sustainability 2019, 11, 1738. [CrossRef]

10. De Villiers, C.; Naiker, V.; van Staden, C.J. The effect of board characteristics on firm environmental performance. J. Manag. 2011, 37, 1636-1663. [CrossRef]

11. Huang, J.W.; Li, Y.H. Green innovation and performance: The view of organizational capability and social reciprocity. J. Bus. Ethics 2017, 145, 309-324. [CrossRef]

12. Tang, M.; Walsh, G.; Lerner, D.; Fitza, M.A.; Li, Q. Green innovation, managerial concern and firm performance: An empirical study. Bus. Strategy Environ. 2018, 27, 39-51. [CrossRef]

13. Li, Y.; Gong, M.; Zhang, X.Y.; Koh, L. The impact of environmental, social, and governance disclosure on firm value: The role of CEO power. Br. Account. Rev. 2018, 50, 60-75. [CrossRef]

14. Saltaji, I.M. Corporate governance relation with corporate sustainability. Intern. Audit. Risk Manag. 2013, 8, 137-147.

15. Naciti, V. Corporate governance and board of directors: The effect of a board composition on firm sustainability performance. J. Clean. Prod. 2019, 237, 117727. [CrossRef]

16. Kaplan, R.S. Strategic performance measurement and management in nonprofit organizations. Nonprofit Manag. Leadersh. 2001, 11,353-370. [CrossRef]

17. Zahra, S.A.; Stanton, W.W. The implications of board of directors composition for corporate strategy and performance. Int. J. Manag. 1988, 5, 229-236. 
18. Jizi, M. The influence of board composition on sustainable development disclosure. Bus. Strategy Environ. 2017, 26, 640-655. [CrossRef]

19. Hansen, E.; Sextl, M.; Reichwald, R. Managing strategic alliances through a community-enabled balanced scorecard: The case of Merck Ltd., Thailand. Bus. Strategy Environ. 2010, 19, 387-399. [CrossRef]

20. Ben-Amar, W.; McIlkenny, P. Board effectiveness and the voluntary disclosure of climate change information. Bus. Strategy Environ. 2015, 24, 704-719. [CrossRef]

21. Revelli, C.; Viviani, J.L. Financial performance of socially responsible investing (SRI): What have we learned? A meta-analysis. Bus. Ethics Eur. Rev. 2015, 24, 158-185. [CrossRef]

22. Landi, G.; Sciarelli, M. Towards a more ethical market: The impact of ESG rating on corporate financial performance. Soc. Responsib. J. 2019, 15, 11-27. [CrossRef]

23. Limkriangkrai, M.; Koh, S.; Durand, R.B. Environmental, social, and governance (ESG) profiles, stock returns, and financial policy: Australian evidence. Int. Rev. Financ. 2017, 17, 461-471. [CrossRef]

24. Chang, Y.K.; Oh, W.Y.; Park, J.H.; Jang, M.G. Exploring the relationship between board characteristics and CSR: Empirical evidence from Korea. J. Bus. Ethics 2017, 140, 225-242. [CrossRef]

25. Oh, W.Y.; Chang, Y.K.; Martynov, A. The effect of ownership structure on corporate social responsibility: Empirical evidence from Korea. J. Bus. Ethics 2011, 104, 283-297. [CrossRef]

26. Bhuiyan, M.B.; Roudaki, J.; Clark, M. The effect of corporate governance regulations on firm value: New Zealand evidence. In Proceedings of the 22nd Asian-Pacific Conference on International Accounting Issues, Gold Coast, QLD, Australia, 7-10 November 2010.

27. Yadav, P.L.; Han, S.H.; Rho, J.J. Impact of environmental performance on firm value for sustainable investment: Evidence from large US firms. Bus. Strategy Environ. 2016, 25, 402-420. [CrossRef]

28. Klassen, R.D.; McLaughlin, C.P. The impact of environmental management on firm performance. Manag. Sci. 1996, 42, 1199-1214. [CrossRef]

29. Ruf, B.M.; Muralidhar, K.; Brown, R.M.; Janney, J.J.; Paul, K. An empirical investigation of the relationship between change in corporate social performance and financial performance: A stakeholder theory perspective. J. Bus. Ethics 2001, 32, 143-156. [CrossRef]

30. Yadav, P.L.; Han, S.H.; Kim, H. Sustaining competitive advantage through corporate environmental performance. Bus. Strategy Environ. 2017, 26, 345-357. [CrossRef]

31. Blacconiere, W.G.; Patten, D.M. Environmental disclosures, regulatory costs, and changes in firm value. J. Account. Econ. 1994, 18, 357-377. [CrossRef]

32. Melnyk, S.A.; Sroufe, R.P.; Calantone, R. Assessing the Impact of Environmental Management Systems on Corporate and Environmental Performance. J. Oper. Manag. 2003, 21, 329-351. [CrossRef]

33. Yawika, M.K.; Handayani, S. The Effect of ESG Performance on Economic Performance in the High Profile Industry in Indonesia. J. Int. Bus. Econ. 2019, 7, 112-121. [CrossRef]

34. Al-Tuwaijri, S.A.; Christensen, T.E.; Hughes, K.E. The Relations Among Environmental Disclosure, Environmental Performance, and Economic Performance: A Simultaneous Equations Approach. Account. Organ. Soc. 2004, 29, 447-471. [CrossRef]

35. Zeng, S.X.; Meng, X.H.; Yin, H.T.; Tam, C.M.; Sun, L. Impact of cleaner production on business performance. J. Clean. Prod. 2010, 18, 975-983. [CrossRef]

36. Jaggi, B.; Freedman, M. An Examination of the Impact of Pollution Performance on Economic and Market Performance: Pulp and Paper Firms. J. Bus. Financ. Account. 1992, 19, 697-713. [CrossRef]

37. Tan, S.H.; Habibullah, M.S.; Tan, S.K.; Choon, S.W. The impact of the dimensions of environmental performance on firm performance in travel and tourism industry. J. Environ. Manag. 2017, 203, 603-611. [CrossRef] [PubMed]

38. Manrique, S.; Martí-Ballester, C.P. Analyzing the Effect of Corporate Environmental Performance on Corporate Financial Performance in Developed and Developing Countries. Sustainability 2017, 9, 1957. [CrossRef]

39. Crifo, P.; Forget, V.D. Think Global, Invest Responsible: Why the Private Equity Industry Goes Green. J. Bus. Ethics 2013, 116, 21-48. [CrossRef]

40. Porter, M.E.; Linde, C.V. Toward a New Conception of the Environment-Competitiveness Relationship. J. Econ. Perspect. 1995, 9, 97-118. [CrossRef] 
41. Peiris, D.; Evans, J. The Relationship Between Environmental Social Governance Factors and U.S. Stock Performance. J. Investig. 2010, 19, 104-114. [CrossRef]

42. Weber, O. Environmental, Social and Governance Reporting in China. Bus. Strategy Environ. 2014, 23, 303-317. [CrossRef]

43. Margolis, J.; Elfenbein, H.A.; Walsh, J. Does It Pay to Be Good ... and Does It Matter? A Meta-Analysis of the Relationship between Corporate Social Responsibility and Financial Performance. Working Paper; Harvard University. 2011. Available online: https://papers.ssrn.com/sol3/papers.cfm?abstract_id=1866371 (accessed on 6 August 2020).

44. Kassinis, G.; Vafeas, N. Corporate boards and outside stakeholders as determinants of environmental litigation. Strateg. Manag. J. 2002, 23, 399-415. [CrossRef]

45. McKendall, M.; Sánchez, C.; Sicilian, P. Corporate governance and corporate illegality: The effects of board structure on environmental violations. Int. J. Organ. Anal. 1999, 7, 201-223. [CrossRef]

46. Hafsi, T.; Turgut, G. Boardroom diversity and its effect on social performance: Conceptualization and empirical evidence. J. Bus. Ethics 2013, 112, 463-479. [CrossRef]

47. Jensen, M.C.; Meckling, W.H. Theory of the firm: Managerial behavior, agency costs and ownership structure. J. Financ. Econ. 1976, 3, 305-360. [CrossRef]

48. Fama, E.F.; Jensen, M.C. Separation of ownership and Control. J. Law Econ. 1983, 26, 301-326. [CrossRef]

49. Wang, J.; Dewhirst, H.D. Boards of Directors and Stakeholder Orientation. J. Bus. Ethics 1992, 11, $115-123$. [CrossRef]

50. Zou, H.L.; Zeng, S.X.; Xie, L.N.; Zeng, R.C. Are Top Executives Rewarded for Environmental Performance? The Role of the Board of Directors in the Context of China. Hum. Ecol. Risk Assess. Int. J. 2015, 21, 1542-1565. [CrossRef]

51. Desender, K.A.; Epure, M. Corporate Governance and Corporate Social Performance: The Influence of Boards, Ownership and Institutions; Barcelona GSE Working Paper No. 730; Department of Economics and Business, Universitat Pompeu Fabra: Barcelona, Spain, 2015; Available online: https://ssrn.com/abstract=2570963 (accessed on 6 August 2020).

52. El Ghoul, S.; Guedhami, O.; Kim, Y. Country-level institutions, firm value, and the role of corporate social responsibility initiatives. J. Int. Bus. Stud. 2017, 48, 360-385. [CrossRef]

53. Ahmed, K.; Hossain, M.; Adams, M. The effect of board composition and board size on the informativeness of annual accounting earning. Corp. Gov. 2006, 14, 418-431. [CrossRef]

54. Biswas, P.K.; Mansi, M.; Pandey, R. Board composition, sustainability committee and corporate social and environmental performance in Australia. Pac. Account. Rev. 2018, 30, 517-540. [CrossRef]

55. Rubino, F.; Napoli, F. What Impact Does Corporate Governance Have on Corporate Environmental Performances? An Empirical Study of Italian Listed Firms. Sustainability 2020, 12, 5742. [CrossRef]

56. Herda, D.N.; Taylor, M.E.; Winterbotham, G. The effect of country-level investor protection on the voluntary assurance of sustainability reports. J. Int. Financ. Manag. Account. 2014, 25, 209-236. [CrossRef]

57. Masud, M.A.K.; Nurunnabi, M.; Bae, S.M. The effects of corporate governance on environmental sustainability reporting: Empirical evidence from South Asian countries. Asian J. Sustain. Soc. Responsib. 2018, 3, 1-26. [CrossRef]

58. Husted, B.W.; Sousa-Filho, J.M. Board structure and environmental, social, and governance disclosure in Latin America. J. Bus. Res. 2019, 102, 220-227. [CrossRef]

59. Ibrahim, N.A.; Angelidis, J. Effect of board members' gender on corporate social responsiveness orientation. J. Appl. Bus. Res. 1994, 10, 35-40. [CrossRef]

60. Haniffa, R.M.; Cooke, T.E. The impact of culture and governance on corporate social reporting. J. Account. Public Policy 2005, 24, 391-430. [CrossRef]

61. Prado-Lorenzo, J.M.; Garcia-Sanchez, I.M. The role of the board of directors in disseminating relevant information on greenhouse gases. J. Bus. Ethics 2010, 97, 391-424. [CrossRef]

62. Jacobs, B.W.; Singhal, V.R.; Subramanian, R. An empirical investigation of environmental performance and the market value of the firm. J. Oper. Manag. 2010, 28, 430-441. [CrossRef]

63. Rao, P.; Holt, D. Do green supply chains lead to competitiveness and economic performance? Int. J. Oper. Prod. Manag. 2005, 25, 898-916. [CrossRef] 
64. Chen, Y.S.; Lai, S.B.; Wen, C.T. The influence of green innovation performance on corporate advantage in Taiwan. J. Bus. Ethics 2006, 67, 331-339. [CrossRef]

65. Aras, G.; Crowther, D. Corporate Sustainability Reporting: A Study in Disingenuity? J. Bus. Ethics 2009, 87, 279-288. [CrossRef]

66. Schuler, D.A.; Cording, M. A corporate social performance-corporate financial performance behavioral model for consumers. Acad. Manag. Rev. 2006, 31, 540-558. [CrossRef]

67. Guthrie, J.; Parker, L.D. Corporate Social Reporting: A Rebuttal of Legitimacy Theory. Account. Bus. Res. 1989, 19, 343-352. [CrossRef]

68. Fatima, A.H.; Abdullah, N.; Sulaiman, M. Environmental Disclosure Quality: Examining the Impact of the Stock Exchange of Malaysia's Listing Requirements. Soc. Responsib. J. 2015, 22, 63-90. [CrossRef]

69. Amato, L.H.; Amato, C.H. Environmental policy, rankings and stock values. Bus. Strategy Environ. 2012, 21, 317-325. [CrossRef]

70. Dunn, P.; Sainty, B. The relationship among board of director characteristics, corporate social performance and corporate financial performance. Int. J. Manag. Financ. 2009, 5, 407-423. [CrossRef]

71. Ntim, C.G.; Lindop, S.; Thomas, D.A. Corporate governance and risk reporting in South Africa: A study of corporate risk disclosures in the pre-and post-2007/2008 global financial crisis periods. Int. Rev. Financ. Anal. 2013, 30, 363-383. [CrossRef]

72. Karamanou, I.; Vafeas, N. The association between corporate boards, audit committees, and management earnings forecasts: An empirical analysis. J. Account. Res. 2005, 43, 453-486. [CrossRef]

73. Li, Z.; Liao, G.; Albitar, K. Does corporate environmental responsibility engagement affect firm value? The mediating role of corporate innovation. Bus. Strategy Environ. 2019, 29, 1045-1055. [CrossRef]

74. Garay, U.; Gonzalez, M. Corporate governance and firm value: The case of Venezuela. Corp. Gov. Int. Rev. 2008, 16, 194-209. [CrossRef]

75. Jo, H.; Harjoto, M.A. Corporate governance and firm value: The impact of corporate social responsibility. J. Bus. Ethics 2011, 103, 351-383. [CrossRef]

76. Kock, C.J.; Diestre, L.; Santaló, J. Corporate Governance and the Environment: What Type of Governance Creates Greener Companies? J. Manag. Stud. 2011, 49, 492-514. [CrossRef]

77. Duuren, E.; Plantinga, A.; Scholtens, B. ESG integration and the investment management process: Fundamental investing reinvented. J. Bus. Ethics 2016, 138, 525-533. [CrossRef]

78. Ammer, M.A.; Ahmad-Zaluki, N.A. The effect of disclosure regulation on the bias and accuracy of management earnings forecasts in Malaysian IPO prospectuses. J. Financ. Report. Account. 2017, 15, 59-77. [CrossRef]

79. Bernardi, C.; Stark, A. Environmental, social and governance disclosure, integrated reporting, and the accuracy of analyst forecasts. Br. Account. Rev. 2018, 50, 16-31. [CrossRef]

80. Kao, M.F.; Hodgkinson, L.; Jaafar, A. Ownership structure, the board of directors and firm performance: Evidence from Taiwan. Corp. Gov. Int. J. Bus. Soc. 2018, 19, 189-216. [CrossRef]

81. Albitar, K.; Hussainey, K.; Kolade, N.; Gerged, A. ESG disclosure and firm performance before and after IR: The moderating role of governance mechanisms. Int. J. Account. Inf. Manag. 2020, 28, 1-21. [CrossRef]

82. Hasan, M.S.; Omar, N. The Impact of Firm's Level Corporate Governance on Market Capitalization. J. Investig. Manag. 2015, 4, 119-131.

83. Abdalkrim, G. Chief executive officer compensation, corporate governance and performance: Evidence from KSA firms. Corp. Gov. 2019, 19, 1216-1235. [CrossRef]

84. Konar, S.; Cohen, M.A. Does the market value environmental performance? Rev. Econ. Stat. 2001, 83, $281-289$. [CrossRef]

85. Johnson, R.; Greening, D. The effects of corporate governance and institutional ownership types on corporate social performance. Acad. Manag. J. 1999, 42, 564-576.

86. Chatterji, A.; Levine, D. Breaking down the wall of codes: Evaluating non-financial performance measurement. Calif. Manag. Rev. 2006, 48, 29-51. [CrossRef]

87. Brooks, C.; Oikonomou, I. The effects of environmental, social and governance disclosures and performance on firm value: A review of the literature in accounting and finance. Br. Account. Rev. 2018, 50, 1-15. [CrossRef]

88. Cek, K.; Eyupoglu, S. Does environmental, social and governance performance influence economic performance? J. Bus. Econ. Manag. 2020, 21, 1165-1184. [CrossRef] 
89. Garcia-Castro, R.; Canela, M.A.; Arino, M.A. Does social performance really lead to financial performance? Accounting for endogeneity. J. Bus. Ethics 2010, 92, 107-126. [CrossRef]

90. Alshehhi, A.; Nobanee, H.; Khare, N. The Impact of Sustainability Practices on Corporate Financial Performance: Literature Trends and Future Research Potential. Sustainability 2018, 10, 494. [CrossRef]

91. Jo, H.; Kim, H.; Park, K. Corporate environmental responsibility and firm performance in the financial services sector. J. Bus. Ethics 2014, 11, 19-35. [CrossRef]

Publisher's Note: MDPI stays neutral with regard to jurisdictional claims in published maps and institutional affiliations.

(C) 2020 by the authors. Licensee MDPI, Basel, Switzerland. This article is an open access article distributed under the terms and conditions of the Creative Commons Attribution (CC BY) license (http://creativecommons.org/licenses/by/4.0/). 